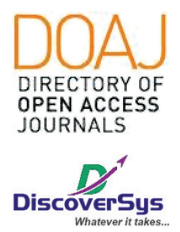

Published by DiscoverSys

\section{Hubungan kontrol glikemik dengan petanda gangguan ginjal dini pada pasien diabetes melitus tipe 2}

\author{
Hadian Widyatmojo, ${ }^{*}$ Indranila Kustarini Samsuria, ${ }^{1}$ Ria Triwardhani ${ }^{2}$
}

\section{ABSTRACT}

Background: Glycemic control in type 2 diabetes mellitus (DM) which can be assessed by examination of fasting blood sugar (FBG) and glycosylated hemoglobin ( $\mathrm{HbA1c})$ is thought to be associated with renal complications. Several markers can be used to assess the rate of damage to early kidney function, such as serum creatinine, urine creatinine albumin ratio ( $\mathrm{ACR}$ ), and serum cystatin C. The relationship of glycemic control with early kidney disorder markers in type 2 DM patients still shows controversial results.. The aim of the study to investigate the relationship between glycemic control (FBG and $\mathrm{HbA1c}$ ) with early kidney disorder markers (serum creatinine, uACR, and cystatin () in patients with type 2 diabetes mellitus.

Methods: Analytic observational study with cross sectional approach conducted in April - June 2019 involved 34 type 2 DM patients in Karang Ayu Health Center who met the inclusion and exclusion criteria. Examination of GDP levels using the hexokinase method, HbA1c levels using the HPLC method, serum creatinine using the Jaffe method, $u A C R$ is calculated based on the ratio between urine albumin and creatinine, and cystatin C levels using the ELISA method. Statistical tests using Spearman's non-parametric correlation with $p<0.05$ were considered significant.

Results: The mean \pm SD FBG and HbA1c levels were $130.41 \pm$ $39.37 \mathrm{mg} / \mathrm{Jd}$ and $8.21 \pm 1.65 \%$. Median (minimum-maximum) serum creatinine levels, uACR and serum cystatin C were $0.63(0.35$ 2.79) $\mathrm{mg} / \mathrm{dL}, 16.55(4.1-29.8) \mathrm{mg} / \mathrm{g}$ and $0.72(0.46-1.22) \mathrm{mg} / \mathrm{L}$. The correlation of FBG levels with serum creatinine, $\mathrm{UACR}$, and serum cystatin ( were $(r=0.016 ; p=0.927),(r=0.293 ; p=0.092)$, and $(r=$ $0.334 ; p=0.053)$. The relationship of HbA1c with serum creatinine, $u A C R$, and cystatin ( was $(r=0.120 ; p=0.495),(r=0.326 ; p=0.059)$; and $(r=0.505 ; p=0.002)$.

Conclusions: There is no relationship between FBG with serum creatinine, $u A C R$, and cystatin $C$. The $H b A 1 c$ value is positively related to cystatin C but not related to serum creatinine and $U A C R$ in patients with type 2 diabetes mellitus.

Keywords: FBG, HbA1c, Creatinine, uACR, Cystatin C, Type 2 Diabetes mellitus.

Cite This Article: Widyatmojo, H., Samsuria, I.K., Triwardhani, R. 2020. Hubungan kontrol glikemik dengan petanda gangguan ginjal dini pada pasien diabetes melitus tipe 2. Intisari Sains Medis 11(2): 476-480. D0I: 10.15562/ism.v11i2.609

\title{
ABSTRAK
}

Latar belakang: Kontrol glikemik pada diabetes melitus tipe 2 (DM) yang dapat dinilai dengan pemeriksaan gula darah puasa (GDP) dan hemoglobin terglikosilasi (HbA1c) diduga berhubungan dengan komplikasi nefropati. Beberapa petanda dapat digunakan untuk menilai menilai kerusakan fungsi ginjal dini, misalnya kreatinin serum, rasio albumin kreatinin urin (UACR), dan cystatin ( serum. Hubungan kontrol glikemik dengan petanda gangguan ginjal dini pada pasien DM tipe 2 masih menunjukkan hasil yang kontroversial. Mengetahui hubungan antara kontrol glikemik (GDP dan HbA1c) dengan petanda gangguan ginjal dini (Kreatinin serum, uACR, dan cystatin C) pada pasien diabetes melitus tipe 2 .

Metode: Penelitian observasional analitik dengan pendekatan belah lintang dilakukan pada bulan April - Juni 2019 melibatkan 34 pasien DM tipe 2 di Puskesmas Karang Ayu yang memenuhi kriteria inklusi dan ekslusi. Pemeriksaan kadar GDP menggunakan metode heksokinase, kadar HbA1c menggunakan metode HPLC, kreatinin serum menggunakan metode Jaffe, uACR dihitung berdasarkan rasio antara albumin dan kreatinin urin, dan kadar Cystatin C menggunakan metode ELISA. Uji statistik menggunakan korelasi non parametrik Spearman dengan $p<0,05$ dianggap signifikan.

Hasil: Rerata \pm SD kadar GDP dan HbA1c adalah 130,41 $\pm 39,37 \mathrm{mg} / \mathrm{dL}$ dan $8,21 \pm 1,65 \%$. Median (minimum-maksimum) kadar kreatinin serum, uACR dan cystatin ( serum berturut-turut adalah 0,63(0,35-2,79) $\mathrm{mg} / \mathrm{dL}, 16,55(4,1-29,8) \mathrm{mg} / \mathrm{g}$, dan 0,72(0,46 - 1,22) mg/L. Korelasi kadar GDP dengan kreatinin serum, uACR, dan cystatin ( serum adalah $(r=0,016 ; p=0,927),(r=0,293 ; p=0,092)$, dan $(r=0,334 ; p=0,053)$. Hubungan $\mathrm{HbA1c}$ dengan kreatinin serum, $\mathrm{uACR}$, dan cystatin ( adalah $(\mathrm{r}=0,120 ; p=0,495),(\mathrm{r}=0,326 ; p=0,059)$; $\operatorname{dan}(\mathrm{r}=0,505 ; p=0,002)$. Simpulan: Tidak terdapat hubungan antara GDP dengan kreatinin serum, uACR, dan cystatin C. Nilai HbA1c berhubungan positif sedang dengan cystatin C namun tidak berhubungan dengan kreatinin serum dan uACR pada pasien diabetes melitus tipe 2 .
Kedokteran Universitas Diponegoro Semarang, Indonesia

hadianwidyatmojo@yahoo.com

Diterima: 06-09-2019

Disetujui: 09-07-2020

Diterbitkan: 01-08-2020
Kata kunci: GDP, HbA1C, Kreatinin, uACR, Cystatin C, DM tipe 2.

Cite Pasal Ini: Widyatmojo, H., Samsuria, I.K., Triwardhani, R. 2020. Hubungan kontrol glikemik dengan petanda gangguan ginjal dini pada pasien diabetes melitus tipe 2. Intisari Sains Medis 11(2): 476-480. D0I: 10.15562/ism.v11i2.609 


\section{PENDAHULUAN}

Diabetes melitus (DM) tipe 2 adalah kondisi hiperglikemia kronik yang memerlukan pemantauan yang ketat oleh karena komplikasi yang dapat terjadi, salah satunya nefropati. ${ }^{1,2}$ Nefropati diabetikum memiliki beberapa faktor risiko salah satunya hiperglikemia. ${ }^{3}$ Kondisi hiperglikemia kronik akan memicu pembentukan advanced glycosylation end-product (AGE) dan sitokin proinflamasi (TNFa, TGF $\beta$, dan IL-6) yang menyebabkan kerusakan pada jaringan, salah satunya ginjal. ${ }^{4}$ Pemeriksaan gula darah puasa (GDP) dan hemoglobin terglikosilasi (HbA1c) merupakan pemeriksaan laboratorium yang digunakan sebagai diagnosis dan monitoring DM. Kadar HbAlc di darah tergantung dari usia sel darah merah, oleh karena itu, selain sebagai penegakkan diagnosis, pemeriksaan $\mathrm{HbAlc}$ digunakan untuk monitoring bulanan tatalaksana DM tipe 2, sedangkan GDP digunakan untuk monitoring harian. ${ }^{2,5}$ Kreatinin merupakan zat metabolisme otot yang disekresikan secara konstan oleh tubuh setiap hari, oleh karenanya dapat digunakan sebagai salah satu petanda kerusakan ginjal. ${ }^{6}$ Pemeriksaan uACR merupakan salah satu pemeriksaan untuk menilai adanya mikroalbuminuria atau makroalbuminuria pada penderita DM. ${ }^{7}$ Albumin merupakan salah satu protein dengan berat molekul kecil yang digunakan sebagai petanda adanya kondisi nefropati pada DM. ${ }^{8}$ Cystatin $C$ merupakan petanda fungsi ginjal dengan berat molekul kecil $(12,8 \mathrm{kDa})$ dan nilai isoelektrik yang tinggi sehingga memudahkan cystatin $C$ melewati glomerulus pada kondisi kerusakan minimal. Cystatin $C$ dipercaya merupakan petanda yang lebih baik dari kreatinin. ${ }^{9}$ Penelitian yang dilakukan oleh Zhou et al. menunjukkan bahwa cystatin $C$ merupakan prediktor signifikan nefropati pada pasien DM. ${ }^{10}$

Hiperglikemia memiliki korelasi dengan gangguan fungsi ginjal pada DM tipe 2. Penelitian ini bertujuan untuk membuktikan hubungan kadar GDP dan $\mathrm{HbAlc}$ sebagai petanda status glikemik dengan kadar kreatinin serum, uACR, dan cystatin $C$ serum sebagai petanda gangguan ginjal dini pada pasien DM tipe 2.

\section{METODE}

Penelitian ini menggunakan pendekatan belah lintang yang dilakukan di Puskesmas Karangayu, Kota Semarang pada bulan April - Juni 2019. Penelitian mengikutsertakan 34 penderita DM tipe 2 dengan usia 45-65 tahun dan onset DM tipe 2 kurang dari 10 tahun, tidak ada keluhan saat penelitian dan suhu tubuh dalam batas normal. Pasien dengan anemia, lekositosis, riwayat keganasan, riwayat penyakit jantung, dan konsumsi obat kortikosteroid dieksklusi pada penelitian ini. Pengambilan sampel menggunakan teknik consecutive sampling terhadap pasien poliklinik prolanis yang bersedia ikut serta dalam penelitian dengan memberikan informed consent. Penelitian ini juga sudah mendapatkan layak etik dari Komite Etik Penelitian Kesehatan (KEPK) Fakultas kedokteran Universitas Diponegoro, nomor: No.220/EC/ KEPK/FK-UNDIP/V/2019.

Pemeriksaan GDP menggunakan metode heksokinase, HbAlc dilakukan menggunakan metode high performance liquid chromatography (HPLC), kreatinin serum diperiksan menggunakan metode Jaffe, uACR dinilai menggunakan rasio antara albumin dan kreatinin urin menggunakan urin sewaktu, sedangkan pemeriksaan cystatin $C$ dilakukan dengan metode enzyme linked immunoabsorbent assay (ELISA) yang keseluruhannya telah dikaliberasi dan dilakukan pemantapan mutu harian yang terdokumentasi. Uji normalitas data menggunakan Saphiro-Wilk, sedangkan uji korelasi pada variabel menggunakan uji non parametrik Spearman. Analisis statistik menggunakan SPSS versi 16.0. Nilai $p<0,05$ dianggap bermakna.

\section{HASIL}

Hasil penelitian dari 34 subyek penelitian, terdiri dari 23 subyek penelitian berjenis kelamin perempuan $(67,6 \%)$ dan 11 subyek penelitian berjenis kelamin laki-laki $(32,4 \%)$. Rentang usia subyek penelitian secara keseluruhan adalah 46-65 tahun dengan rerata usia 55,66 $\pm 6,36$ tahun, dengan nilai tengah usia 56 tahun. Data ditampilkan sebagai nilai rerata \pm SB (Simpang baku/Standar deviasi), dan nilai median (minimum - maksimum). Data karakteristik dasar subyek penelitian dapat dilihat pada tabel 1.

Hubungan antara kadar GDP dengan kreatinin serum, uACR, dan cystatin $C$ menggunakan uji korelasi non parametrik Spearman. Hasil uji hubungan antara GDP dengan kreatinin serum, uACR dan cystatin $C$ masing-masing didapatkan $\mathrm{r}=0,016 ; p=0,927, \mathrm{r}=0,293 ; p=0,092$, dan $\mathrm{r}=0,334$; $p=0,053$. Uji hubungan antara GDP dengan petanda gangguan ginjal dini didapatkan simpulan tidak terdapat hubungan. Hasil uji korelasi GDP dengan kreatinin serum, uACR, dan cystatin $C$ dapat dilihat pada tabel 2.

Hubungan antara nilai $\mathrm{HbAlc}$ dengan kreatinin serum, uACR, dan cystatin $C$ serum menggunakan uji korelasi non parametrik Spearman. Hasil uji hubungan antara kadar HbAlc dengan kreatinin serum, uACR, dan cystatin $C$ serum diperoleh masing-masing $\mathrm{r}=0,120 ; \quad p=0,495, \quad \mathrm{r}=0,326 ; \quad p=$ 0,059 ; dan $\mathrm{r}=0,505 ; p=0,002$, artinya terdapat 
Tabel 1 Data karakteristik dasar penelitian

\begin{tabular}{|c|c|c|c|c|}
\hline Karakteristik & $\mathbf{n}$ & $\%$ & Rerata \pm SB & Median (min - maks) \\
\hline \multicolumn{5}{|l|}{ Jenis kelamin } \\
\hline Laki-laki & 11 & 32,4 & & \\
\hline Perempuan & 23 & 67,6 & & \\
\hline Usia (tahun) & & & $54,03 \pm 10,28$ & $56,5(46-65)$ \\
\hline IMT (kg/m2) & & & $26,65 \pm 3,94$ & $25,76(17,31-36,33)$ \\
\hline GDP $(\mathrm{mg} / \mathrm{dL})$ & & & $130,41 \pm 39,37$ & $114(85-230)$ \\
\hline HbAlc (\%) & & & $8,21 \pm 1,65$ & $8,35(5,7-12,9)$ \\
\hline Kreatinin (mg/dL) & & & $0,75 \pm 0,47$ & $0,63(0,35-2,79)$ \\
\hline uACR (mg/g) & & & $16,84 \pm 8,09$ & $16,55(4,1-29,8)$ \\
\hline Cystatin C (mg/L) & & & $0,74 \pm 0,14$ & $0,72(0,46-1,22)$ \\
\hline
\end{tabular}

SB: simpang baku, min: mininum, maks: maksimum, IMT: indeks massa tubuh, GDP:Gula darah puasa, uACR: urine Albumin creatinine ratio.

Tabel 2 Hubungan GDP dengan petanda gangguan ginjal dini

\begin{tabular}{lcccc}
\hline & \multicolumn{2}{c}{ GDP } & \\
\cline { 2 - 3 } Parameter & $\boldsymbol{p}$ & $\mathbf{r}$ & Keterangan \\
\hline Kreatinin serum & 0,927 & 0,016 & Tidak signifikan \\
uACR & 0,092 & 0,293 & Tidak signifikan \\
Cystatin C & 0,053 & 0,334 & Tidak signifikan \\
\hline
\end{tabular}

Tabel 3 Hubungan $\mathrm{HbA1}$ c dengan petanda gangguan ginjal dini

\begin{tabular}{lccc}
\hline & \multicolumn{2}{c}{ HbA1c } & \\
\cline { 2 - 3 } Parameter & $\boldsymbol{p}$ & $\mathbf{r}$ & Keterangan \\
\hline Kreatinin serum & 0,495 & 0,120 & Tidak signifikan \\
uACR & 0,059 & 0,326 & Tidak signifikan \\
Cystatin $C$ & 0,002 & 0,505 & Signifikan, positif sedang \\
\hline
\end{tabular}

hubungan positif sedang antara $\mathrm{HbAlc}$ dengan cystatin $C$ serum, sedangkan antara $\mathrm{HbA1c}$ dengan petanda lain tidak berhubungan. Uji hubungan antara $\mathrm{HbAlc}$ dengan kreatinin serum, uACR, dan cystatin $C$ serum pada pasien DM tipe 2 dapat dilihat pada tabel 3 .

\section{PEMBAHASAN}

Jenis kelamin pada subyek penelitian terdiri dari 23 berjenis kelamin perempuan $(67,6 \%)$ dan 11 lakilaki $(32,4 \%)$ dengan rerata usia 55,66 $\pm 6,36$ tahun dan rentang usia 46-65 tahun. Data ini sesuai dengan Riskesdas 2018 yang melaporkan prevalensi penderita DM lebih tinggi pada perempuan $(1,8 \%)$ dibandingkan laki-laki (1,2\%) dengan rentang usia terbanyak penderita pada usia 45-64 tahun. ${ }^{11}$ Usia merupakan salah satu faktor risiko terjadinya DM tipe 2. Data di Amerika Serikat (AS) menunjukkan usia diatas 45 tahun memiliki kecenderungan menderita DM 8 kali lipat (20\%) lebih tinggi dibandingkan usia $18-44$ tahun $(2,4 \%){ }^{12}$ Peningkatan prevalensi DM tipe 2 pada usia lanjut berhubungan dengan terjadinya penurunan fungsi sel $\beta$ pankreas yang memproduksi insulin didalam tubuh sehingga mempengaruhi kemampuan ambilan glukosa ke dalam jaringan. ${ }^{13}$

Indeks massa tubuh (IMT) pada subyek penelitian memiliki rerata $26,65 \pm 10,28 \mathrm{~kg} / \mathrm{m}^{2}$ dengan median $25,76 \mathrm{~kg} / \mathrm{m}^{2}$, nilai minimum $17,31 \mathrm{~kg} / \mathrm{m}^{2}$ dan maksimum $36,33 \mathrm{~kg} / \mathrm{m}^{2}$. Menurut klasifikasi WHO, rerata IMT pada penelitian ini masuk dalam kategori overweight. ${ }^{14}$ Hasil penelitian ini sesuai dengan penelitian yang dilakukan oleh Mihardja, et al. dimana kondisi overweight dan obesitas memiliki prevalensi tinggi menderita DM tipe $2(68,4 \%) \cdot{ }^{15}$ Penelitian yang dilakukan oleh Ganz, et al. menyebutkan peningkatan IMT meningkatkan risiko terjadinya DM tipe $2 .{ }^{16}$ Peningkatan IMT pada DM dapat menyebabkan dan memperberat resistensi insulin. Jaringan adiposa yang berlebih berkontribusi dalam peningkatan asam lemak 
dalam darah yang akan menyebabkan akumulasi lemak di otot dan hati, serta peningkatan diasilgliserol yang akan mengaktifkan protein kinase $\mathrm{C}$ (PKC) yang menghambat sinyal insulin seluler. Efek merugikan dari beberapa sitokin seperti TNF $\alpha$ dan IL6 yang diproduksi secara berlebihan oleh jaringan adiposa dan berkurangnya produksi adiponektin adalah mekanisme yang dapat meningkatkan terjadinya DM tipe $2 . .^{17,18}$

Pada subyek didapatkan kadar GDP meningkat dengan rerata $130,41 \pm 39,37 \mathrm{mg} / \mathrm{dL}$, yang menunjukan bahwa kontrol harian tidak dalam kondisi baik, sedangkan parameter petanda gangguan ginjal dini masih dalam rentang normal. Hasil penelitian ini tidak didapatkan hubungan antara GDP dengan petanda gangguan ginjal dini pada DM tipe 2. Hal ini dapat disebabkan oleh karena pada subyek masih belum terjadi gangguan ginjal yang berat.

Pada subyek didapatkan nilai HbAlc meningkat dengan rerata $8,21 \pm 1,65 \%$ yang menandakan kontrol glikemik yang buruk. Nilai HbAlc hanya berhubungan signifikan dengan kadar cystatin $C$ serum dengan nilai $p=0,002$ dan $r=0,505$. Hasil ini menunjukkan bahwa kontrol glikemik yang buruk dapat meningkatkan risiko gangguan fungsi ginjal dini pada DM tipe 2. Hasil penelitian ini sesuai dengan penelitian yang dilakukan oleh El-Kafrawy, et al. dimana didapatkan $\mathrm{HbAlc}$ memiliki korelasi sedang dengan cystatin $C$ dengan $p=0,000$ dan $\mathrm{r}=0,56 .{ }^{19}$ Penelitian lain oleh Cheng, et al. menyimpulkan bahwa nilai $\mathrm{HbAlc}$ secara independen berkaitan dengan progresifitas status ginjal pada pasien DM. ${ }^{20}$

Hemoglobin terglikosilasi (HbA1c) terbentuk dari kondensasi glukosa dengan residu $\mathrm{N}$-terminal valine setiap rantai $\beta$ pada $\mathrm{HbA}$ untuk membentuk schiff base yang tidak stabil. Schiff base yang terbentuk kemudian mengalami Amadori rearrangement untuk membentuk ketoamin yang stabil yaitu $\mathrm{HbA1c}$, oleh karena itu HbA1c merupakan indikator penting kontrol glikemik jangka panjang yang merefleksikan kondisi glukosa darah dua sampai tiga bulan sebelumnya dan memiliki korelasi dengan risiko komplikasi kronik pada DM tipe 2. ${ }^{21}$

Peningkatan glukosa akan mengaktifkan jalur sinyal seluler seperti diasilgliserol-PKC, AGEs dan stres oksidatif yang merupakan kunci dalam terjadinya kerusakan glomerulus pada DM. ${ }^{22}$ Advanced glycation end products (AGEs) merupakan hasil glikasi protein ireversibel. Produk AGEs yang sudah terbentuk akan merusak sel dengan memodifikasi atau merusak fungsi protein intraseluler dan ekstraseluler, misalnya AGEs memodifikasi kolagen tipe IV yang menyebabkan peningkatan permeabilitas membran basal glomerulus. Peningkatan
AGEs juga akan menyebabkan peningkatan kepadatan dan ekspansi matriks ekstraseluler di ginjal. ${ }^{23}$ Matriks ekstraseluler merupakan perubahan morfologis utama yang menyebabkan penebalan membran basalis dan perluasan matriks mesangial glomerulus, hal ini menyebabkan penurunan fungsi ginjal dan kebocoran albumin. ${ }^{24,25}$

Cystatin $C$ diproduksi konstan oleh sel berinti, difiltrasi oleh glomerulus dan di metabolisme oleh tubulus proksimal. Cystatin $C$ merupakan biomarker endogen untuk menilai gangguan fungsi ginjal oleh karena memiliki korelasi dengan LFG dan albuminuria. ${ }^{25-27}$ Penelitian lain menyebutkan bahwa cystatin $C$ serum merupakan petanda awal kerusakan ginjal pada pasien DM. ${ }^{27-29}$

Sebagai parameter kontrol glikemik, peningkatan HbAlc menggambarkan kondisi hiperglikemik kronik. Hubungan antara peningkatan HbAlc dengan kerusakan ginjal menandakan kondisi hiperglikemik yang terus berlangsung. Kadar HbAlc digunakan sebagai petanda kontrol glikemik yang berperan dalam komplikasi kronik pada DM tipe 2 dan cystatin $C$ sebagai petanda awal gangguan ginjal pada DM tipe 2.

\section{SIMPULAN}

Penelitian ini membuktikan adanya hubungan positif sedang bermakna antara kadar $\mathrm{HbAlc}$ dengan kadar cystatin $C$ serum pada pasien diabetes melitus tipe 2. Hiperglikemia yang dinilai dengan $\mathrm{HbAlc}$ merupakan faktor risiko terhadap gangguan ginjal dini yang dapat dinilai dengan cystatin $C$ serum pada pasien DM tipe 2. Penelitian ini tidak membedakan subyek pria dan wanita, serta tidak melakukan pemeriksaan urinalisis untuk melihat adanya kelainan fungsi tubulus yang dapat berpengaruh pada petanda gangguan ginjal.

\section{KONFLIK KEPENTINGAN}

Penulis menyatakan tidak terdapat suatu konflik kepentingan dalam publikasi dari artikel ini.

\section{PENDANAAN}

Penelitian ini tidak mendapatkan pendanaan dari pemerintah maupun lembaga swasta lainnya.

\section{DAFTAR PUSTAKA}

1. PERKENI. Konsensus pengendalian dan pencegahan diabetes melitus Tipe 2 di Indonesia. Jakarta: PERKENI; 2015.

2. Papatheodoru K, Papanas N, Banach M, Papazoglu D, Edmonds M. Complications of diabetes. J of Diabetes Res. 2016;1(2):1-3.

3. Dabla P. Renal function in diabetic nephropathy. World J Diabetes. 2010;1(2): 48-56. 
4. World Health Organization. Use of glycated hemoglobin in the diagnosis of diabetes mellitus. Geneva: World Health Organization; 2011.

5. Suryaatmadja M. Pemeriksaan kadar HbAlc untuk diagnosis prediabetes. In: Pendidikan Berkesinambungan Patologi Klinik 2013. Jakarta: FKUI;2013. P.57-69.

6. Deepa K, Manjunatha G, Oinam S, Devaki R, Bhavna N, Asha $\mathrm{P}$, et al. Serum urea, creatinine in relation to fasting plasma glucose levels in type 2 diabetes. Int J Pharm Bio Sci. 2011;1(1):279-83.

7. Bloomgarden Z. Diabetic nephropathy. Diabetes care. 2005;28(1):745-51.

8. Eddy A. Proteinuria and interstitial injury. Nephrol Dial Transplant. 2004;19(1):277-81.

9. Bassiouny K, Khalil H, Abed-Elmaghed W, El-Halfawey H. Serum cystatin $c$ as an early and efficacious biomarker of diabetic nephropathy. American Journal of Medicine and Medical Sciences. 2015, 5(5): 246-252.

10. Zhou B, Zou H, Xu G. Clinical utility of serum cystatin c in predicting diabetic nephropathy among diabetes mellitus patients. Kidney Blood Press Res. 2016;41:919-928.

11. Badan Penelitian dan Pengembangan Kesehatan Kementerian Kesehatan Republik Indonesia. Riskesdas 2018. Jakarta: Kementerian Kesehatan Republik Indonesia. 2018.

12. Selvin E, Parrinello C. Age-related differences in glycaemic control in diabetes. Diabetologia. 2013; 56(12):1-5.

13. Lee P, Halter J. The pathophysiology of hyperglycemia in older adults:clinical considerations. Diabetes Care. 2017;40(4):444-452.

14. World Health Organization. Appropriate body-mass index for Asian population and its implications for policy and itervention strategies. Lancet. 2004;363(1):157-163.

15. Mihardja L, Soetrisno U, Soegondo S. Prevalence and clinical profile of diabetes mellitus in productive aged urban Indonesians. J Diabetes Investig. 2014;5(5):507-512.

16. Ganz M, Wintfeld N, Li Q, Alas V, Langer J, Mete H. The association of body mass index with the risk of type 2 diabetes: a case control study nested in an electronic health records system in the united states. Diabetology \& Metabolic Syndrome. 2014;50(6):1-8.

17. Day C, Bailey C. Obesity in the pathogenesis of type 2 diabetes. Br J Diabetes Vasc Dis. 2011;11(2):55-61.

18. Pedrini M. Human Trigliseride-rich lipoproteins impair glukose metabolism and insulin signalling in IL 6 skletal muscle cells independently of non esterified fatty acid levels. Diabetologia. 2010;48(4):756-66.

19. El-Kafrawy N, Shohaib A, El-Deen S, El Babbary H, Seleem A. Evaluation of serum cystatin $c$ as an indicator of early renal function decline in type 2 diabetes. Menoufia Med J. 2014;27(2):60-65.
20. Cheng D, Fei Y, Liu Y, Li J, Xue Q, Wang X. HbAlc variability and the risk of renal status progression in diabetes mellitus: A Meta Analysis. PloS One. 2014;9(12):1-13.

21. Sherwani S, Khan H, Ekhzaimy A, Masood A, Sakharkar M. Significance of HbAlc test in diagnosis and prognosis of diabetic patients. Biomark Insight. 2016;11(7):95-104.

22. Sulaiman M. Diabetic nephropathy:recent advances in pathophysiology and challenges in dietary management. Diabetol Metab Syndr. 2019;11(7):1-5.

23. Toth-Manikowski S, Atta M. Diabetic kidney disease:Pathophysiology and therapeutic targets. J Diabetes res 2015;5(5):1-16.

24. Kolset S, Reinholt F, Jenssen T. Diabetic nephropathy and extracellular matrix. J Histochem Cytochem. 2012;60(12):976-986.

25. Jeon Y, Kim M, Kang S. Cystatin C as an early marker of diabetic nephropathy in patients with type 2 diabetes. Clin Lab. 2013;59(11):1221-1229.

26. Futrakul N, Futrakul P. Biomarker for early renal microvascular and diabetic kidney disease. Renal Failure. 2017;39(1):505-511.

27. Gamayanti K, Ratnasari N, Bhargah A. Pola penggunaan insulin pada pasien diabetes mellitus tipe 2 di poli penyakit dalam RSU Negara Periode Juli - Agustus 2018. Intisari Sains Medis.2019;9(3):68-73. DOI:10.15562/ism.v9i3.306

28. Artha IMJR, Bhargah A, Dharmawan NK, Pande UW, Triyana KA, Mahariski PA, Yuwono J, Bhargah V, Prabawa IPY, Manuaba IBAP, Rina IK. High level of individual lipid profile and lipid ratio as a predictive marker of poor glycemic control in type-2 diabetes mellitus. Vasc Health Risk Manag. 2019;15:149-157. doi: 10.2147/VHRM. S209830. PMID: 31239693; PMCID: PMC6560183.

29. Pertiwi GAR, Aryawangsa AAN, Prabawa IPY, Manuaba IBAP, Bhargah A, Budiana IPG. Factor associated with visit-to-visit variability of blood pressure in hypertensive patients at primary health care service, Tabanan, Bali, Indonesia. FMCH. 2018;6(4):191-199. DOI: https://doi.org/10.15212/FMCH.2018.0124.

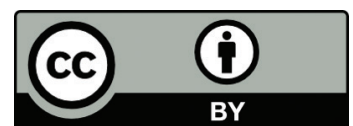

This work is licensed under a Creative Commons Attribution 